\title{
Fertility Preference Inversely Related to 'Legacy Drive' in Women, But Not in Men: Interpreting the Evolutionary Roots, and Future, of the 'Childfree' Culture
}

\author{
Lonnie W. Aarssen* and Stephanie T. Altman
}

Department of Biology, Queen's University, Kingston, ON, Canada K7L 3N6

\begin{abstract}
Online survey results for a university sample population indicated that both male $(n=361)$ and female $(n=764)$ participants had a mean desired lifetime fertility of 2.2 offspring. For females, desired fertility had a significant negative relationship with level of interest in life course goals associated with a rewarding career, acquiring fame, and making contribution to ideas and discoveries, but a significant positive relationship with the goal of inspiring others with one's religious beliefs. In contrast for males, none of these life goals was related to variation in lifetime fertility preference. We interpret these data in the context of the 'transmission competition' hypothesis - an evolutionary explanation for decreasing fertility in developed countries, where for females, gene transmission is limited by competition from 'meme transmission', the latter represented in modern times by the pursuit and achievement of life course goals perceived as providing an enduring personal legacy. This accounts, we suggest, for the origin of the now popular 'childfree' culture. Attraction to accomplishment-based memetic legacy and the childfree lifestyle will eventually be eclipsed, we predict-again because of the effects of natural selection-by an emerging culture driven to a large extent by an intrinsic attraction to parenthood-'parenting drive'.
\end{abstract}

Keywords: Childfree culture, fertility preference, legacy, leisure, meme transmission, parenting drive, religiosity, female empowerment.

\section{INTRODUCTION}

Over the past several decades, the average lifetime fertility for women has dropped conspicuously below replacement level (2.1 offspring) in most developed countries [1]. When women today acquire independent wealth and power over their own fertility, a significant proportion decide (e.g. by choosing to use contraception) to have few, or no children at all [2]. Most hypotheses for this striking trend of declining fertility preference have been proposed based on purely socio-cultural/economic factors, e.g. connected with lifestyle choices that involve postponing (displacing) parenthood to midlife, or trading off a larger family for more materialism, more leisure, or better opportunities per child [3-6]. By comparison, few interpretations have focused on explanations rooted in evolutionary theory [7-9]. Here it is important to distinguish explanations (for fertility variance) where low fertility is associated with 'optimum family size' under certain conditions [10], from explanations for rejection of fertility altogether. The latter is associated with conspicuous derogation and rejection of parenthood-embodied by the socalled 'childfree' culture [11] —now sweeping across the developed world. More than twenty recently published books extol its virtues, virtually all of which involve maximizing opportunity for leisure and personal life goals/achievements

\footnotetext{
*Address correspondence to this author at the Department of Biology, Queen's University, Kingston, ON, Canada K7L 3N6; Tel: 613-533-6133; Fax: 613-533-6617; E-mail: aarssenl@queensu.ca
}

[12-34]. According to a recent report from the Pew Research Center, for American women between 40 and 44 years of age, those without children have increased from 10 percent in 1976 to 18 percent in 2008 [35]. Similar values for childlessness have been reported recently for several European countries [35], as well as in Australia [36], and New Zealand [37].

Below-replacement fertility therefore may be explained to a large extent, not so much as an evolved reproductive strategy where fitness is promoted by parents seeking to maximize individual offspring endowment (achieved by favoring small family size) - but rather, as a consequence of many women simply deciding (even in early adulthood) to forgo motherhood completely. The puzzling question of course is, why? To the biologist, popular behaviors that explicitly promote complete rejection of fertility represent a paradox: they result in zero fitness through direct lineage. An evolutionary perspective, therefore, leads one to ask whether such widespread, cross-cultural behavior might be rooted somehow, at least to some extent, in the effects of genes inherited from ancestors. One such hypothesis is the 'transmission competition' hypothesis [38, 39], involving conflict between behaviors that promote offspring production (gene transmission, i.e. fitness) and those that promote memetic legacy through personal achievements ('meme transmission'). The latter is proposed as a byproduct of Darwinian natural selection for memetic legacy rooted ancestrally in the perception of offspring as vehicles for meme transmission, 
which of course has no conflict with gene transmission. But this byproduct has been allowed to compete with (and suppress) gene transmission only in very recent times as females have acquired significant freedom from patriarchal subjugation, including greater control over their own fertility, combined with greater independence for pursuing both their own accomplishment-based memetic legacy, as well as their own leisure-both of which compete with time and energy required for producing offspring. [See Discussion for an extended account of this interpretation].

The transmission-competition hypothesis, therefore, predicts that women (compared with men) should display a stronger signal of competition (negative relationship) between preferences that promote genetic legacy and those that promote accomplishment-based memetic legacy. To explore this, we surveyed a sample population with upper-level education from a Canadian University to measure individual variation in fertility preference (conferring genetic legacy), and to examine its relationship with individual variation for interest in typical life goals/personal achievements that may be regarded as a manifestation of attraction to accomplishment-based memetic legacy.

\section{METHODS}

Affiliates of Queen's University were invited by electronic mail to participate voluntarily in an online survey. Participants were asked: how many biological offspring would you like to have (or like to have had) over your lifetime? Participants were also asked: indicate - on a scale of 1 (strongly disagree) to 5 (strongly agree) - the extent to which each of the following represents an important goal in your life: to be financially wealthy; to have a rewarding career; to achieve fame for something; to generate new ideas or discoveries; and to inspire others with your religious beliefs. For each goal, the relationship between its score and desired lifetime fertility was analyzed using Spearman rank correlation $\left(r_{\mathrm{s}}\right)$.

\section{RESULTS}

Responses were received from 1,115 participants, involving 351 males and 764 females (reflecting a strongly female biased sex ratio among resident students), and including undergraduate students $(\mathrm{N}=435)$, graduate students $(\mathrm{N}=583)$, and faculty members $(\mathrm{N}=107)$. Desired lifetime fertility did not differ between males (mean=2.20) and females (mean=2.24; $P=0.278$; Mann-Whitney rank sum test; Fig. 1). Males and females also indicated similar interests in financial wealth (Fig. 2a) and a rewarding career (Fig. 2b). Males indicated a significantly stronger interest in fame (Fig. 2c), and in generating ideas and discoveries as lifetime goals (Fig. 2d), but none of the goals examined was related to lifetime fertility preferences in males; not financial wealth $\left(r_{\mathrm{s}}=-\right.$ $0.0169 ; P=0.752)$, rewarding career $\left(r_{\mathrm{s}}=-0.0212 ; P=0.692\right)$, achieving fame $\left(r_{\mathrm{s}}=-0.0166 ; P=0.756\right)$, contributing ideas and discoveries $\left(r_{\mathrm{s}}=-0.0223 ; P=0.677\right)$, nor religious inspiration $\left(r_{\mathrm{s}}=-0.0744 ; P=0.165\right)$. In contrast, however, females that wanted fewer offspring generally had greater interest in a rewarding career $\left(r_{\mathrm{s}}=-0.0686 ; P=0.0578\right)$, greater interest in fame (Fig. 3a), greater interest in generating ideas and discoveries (Fig. 3b), and generally less interest in inspiring
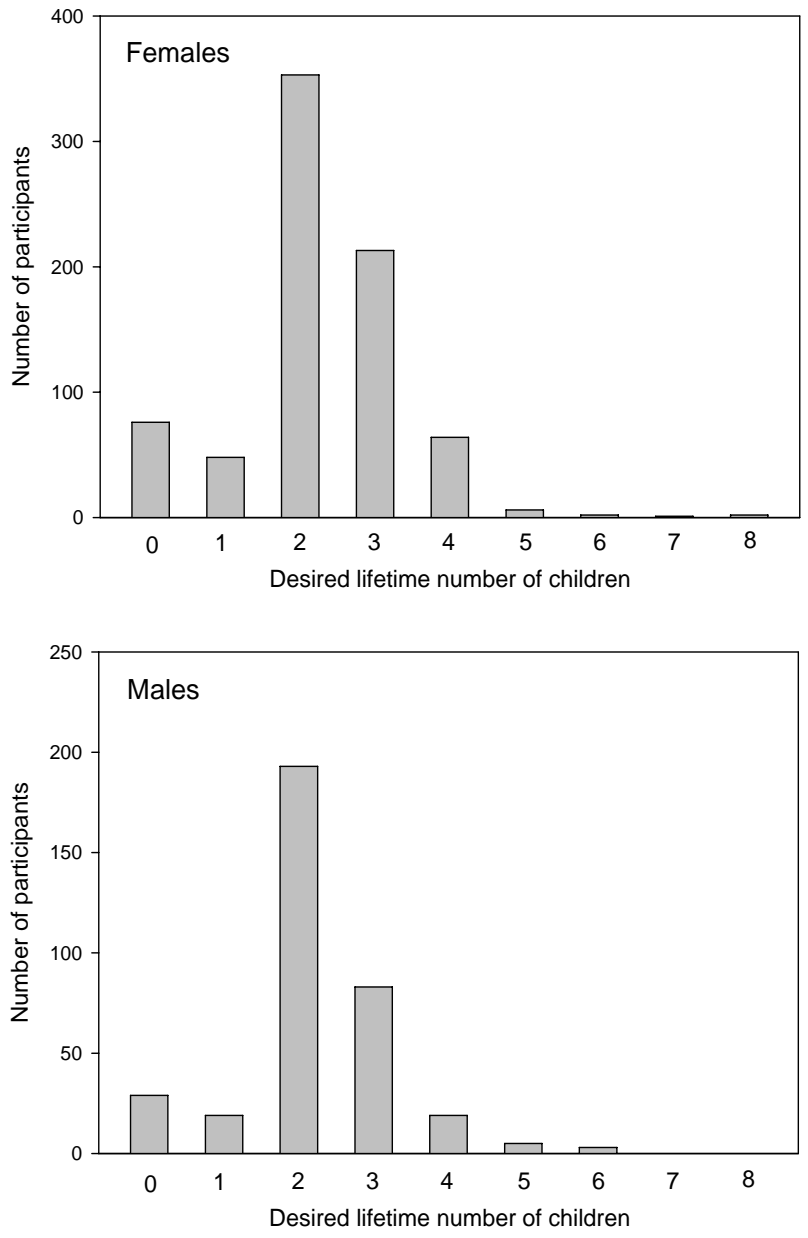

Fig. (1). Frequency distribution of desired lifetime fertility for male $(\mathrm{N}=351)$ and female $(\mathrm{N}=764)$ survey participants from Queen's University, Canada.

others with their religious beliefs (Fig. 3c). Like males, females also showed no relationship between desired lifetime fertility and level of interest in financial wealth $\left(r_{\mathrm{s}}=0.0413\right.$; $P=0.254$ ). The above trends were unaffected when data for only students were analyzed; e.g. correlation for female students $(\mathrm{N}=708)$ between fertility preference and interest in generating ideas and discoveries: $r_{\mathrm{s}}=-0.144 ; P<0.0001$.

\section{DISCUSSION}

Both male and female participants displayed wide variation in fertility preference (Fig. 1), but only in women was this variation correlated (negatively) with levels of interest in life goals reflecting indicators of accomplishment-based memetic legacy drive. Women with relatively high fertility preference tended also to have relatively little interest in achieving fame (Fig. 3a). Women who indicated a desire for few or no children tended to have a relatively strong interest in goals associated with generating new ideas or discoveries (Fig. 3b), and the same women tended to have relatively little interest in inspiring others with their religious beliefs (Fig. 3c). Unlike other 'legacy drive' domains of meme transmission therefore, our results suggest that devotion to religion - arguably a plausible motive for 'leaving some- 

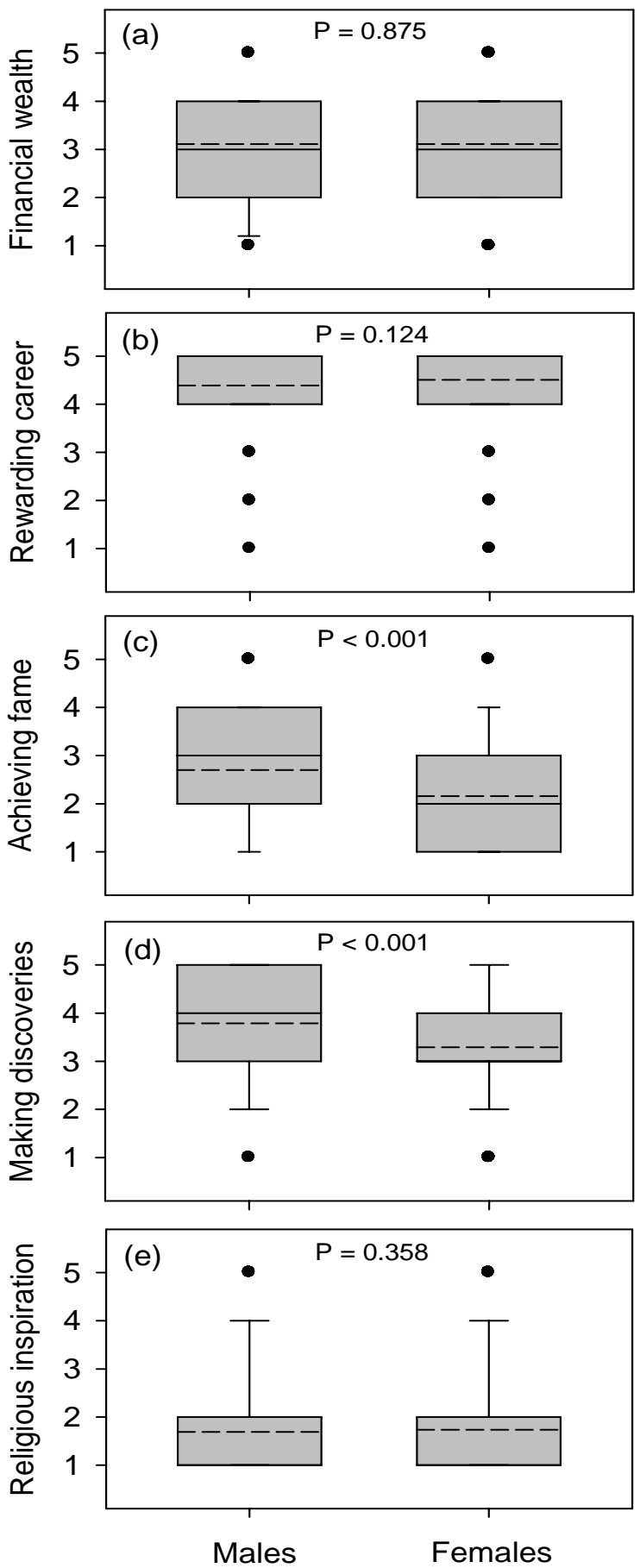

Fig. (2). Box plots comparing male $(\mathrm{N}=351)$ and female $(\mathrm{N}=764)$ survey participants for their level of interest in five lifetime goals: (a) financial wealth; (b) rewarding career; (c) achieving fame; (d) generating new ideas or discoveries; and (e) inspiring others with one's religious beliefs. $P$-values are from Mann-Whitney rank sum tests. Box boundaries represent the $25^{\text {th }}$ and $75^{\text {th }}$ percentiles; whiskers represent the10th and 90th percentiles; points represent outliers; solid line within the box marks the median; dashed line indicates the mean.

thing of oneself for the future' - does not compete with gene transmission. In fact, relatively high fertility associated with religious devotion is well known-e.g. historically in the Roman Catholic faith [40] — but in our data this was true only for women. Previous reports indicate generally greater involvement of women (compared with men) in religious activity in most societies [41], but our measure of religiosity showed no difference based on gender (Fig. 2e). Overall interest in religious inspiration, however, was very low for both males and females - $80 \%$ of all respondents gave a score of only 1 or 2 (out of 5) (Fig. 2e) - and this is consistent with results from other recent surveys showing a striking decline for interest in religiosity in North America [42].

Not surprisingly for students of higher education, the vast majority of participants - both male and female - had strong interest in a rewarding career (Fig. 2b), and this was negatively correlated with interest in religious inspirationsignificantly for women $\left(r_{\mathrm{s}}=-0.121 ; P<0.0001\right)$, but less so for men $\left(r_{\mathrm{s}}=-0.091 ; P=0.091\right)$. Certainly the universityeducated are not representative of the general population hence limiting the potential for detecting a significant general relationship between a 'rewarding career' goal, for example, and fertility preferences (a weak negative relationship was evident for women only; $r_{\mathrm{s}}=-0.0686, P=0.0578$ ). Responses to the question about rewarding career, however, serve as a reliable test of the honesty of participants; virtually everyone involved with learning or teaching at a university presumably has a 'rewarding career' as an important life goal, and indeed virtually all participants indicated this.

Importantly for males, the data indicate that there is no detectable conflict between aspirations linked to gene transmission and aspirations linked to meme transmission - despite the presumed contemporary cultural norm for young men in North American to generally anticipate equal duties in child rearing. Males displayed significantly stronger overall attraction to legacy through ambition (Fig. 2c, d), and yet their average fertility preference was not lower than for females. In contrast for women, behavioural preferences associated with gene transmission (relatively high fertility preferences) generally compete with those associated with personal achievement, and these relationships in our data were obviously unaffected by prior experience with either parenthood or career success, as the vast majority of participants were students who had not yet produced offspring, or pursued a career.

Behavioural preference for relatively low fertility has been previously interpreted as an evolved inclination for an optimal 'offspring endowment' strategy, associated with an offspring quantity/quality tradeoff [43]. Our data suggest, however, that many contemporary women are inclined to prefer low fertility simply because when empowered with the freedom of personal choice, women will readily compromise investment in offspring in order to pursue accomplishment-based memetic legacy. These results raise two central questions: First, what are the sources of betweenindividual variation in memetic legacy drive in women, and what are the sources of between-individual variation in fertility preference - what might be called 'parenting drive' [39]? Most plausibly, as with many human behavioral traits [44], these will be products of socio-cultural construction (individual variation in experience from socio-cultural learning), interacting with effects of genetic variation - and thus, at 

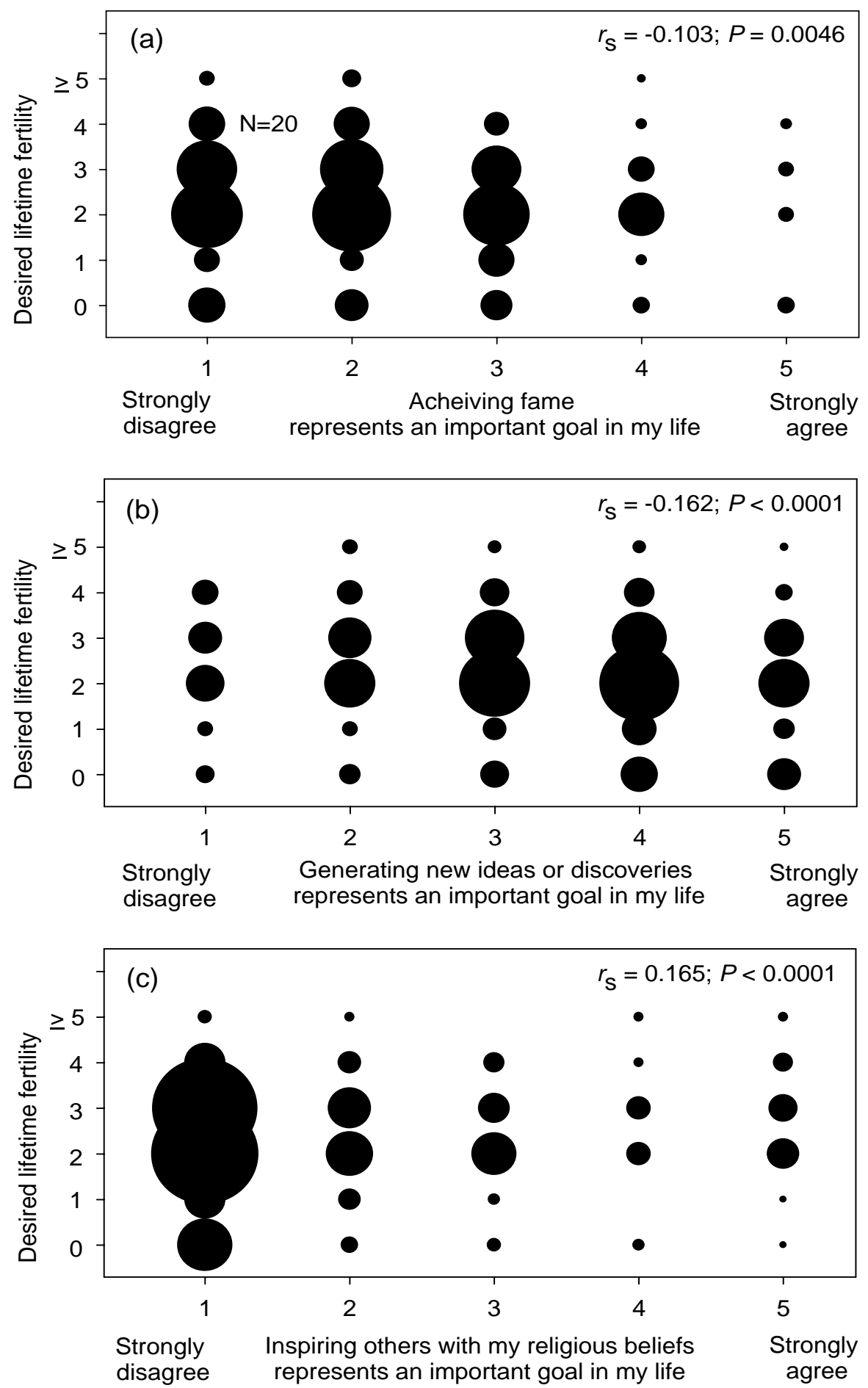

Fig. (3). Bubble plots showing the relationships, for female survey participants ( $N=764)$, between desired lifetime fertility and level of interest in three lifetime goals: (a) achieving fame; (b) generating new ideas or discoveries; (c) inspiring others with one's religious beliefs. The area of the bubble is proportional to the number of individuals with the same data point; one bubble representing $\mathrm{N}=20$ is shown for scale in (a). $r_{\mathrm{s}}$ and associated $P$-values are from Spearman-rank correlation analyses.

least partially subject to effects of Darwinian natural selection. Second (following the latter proposition), how could natural selection have possibly played any role in the evolution of memetic legacy drive when, for many (and a growing number of) women, it is associated with an obvious penalty on fitness through direct lineage: an explicit desire for a completely childfree life? Below, we explore a possible explanation.

\section{'Legacy Drive' and Interpretation of the 'Childfree' Cul- ture}

According to the 'transmission competition' hypothesis [38], humans have acquired, by natural selection, a funda- 
mental attraction to both leisure and legacy-leaving 'something of oneself for the future' - as a response to the evolution of consciousness, the latter being fundamentally associated with anguish from knowing that we are not immortal. The chain of 'effect from cause' then is proposed as follows $[39,45]$ : fitness has been generally promoted by selection for attraction to the 'idea' of memetic legacy through offspring production (which of course confers gene transmission directly) - a particular product of selection for a general attraction to memetic legacy per se, i.e. a comfort afforded by a delusion that the transmission of one's resident 'memes' into the future will confer an enduring legacy of the 'self', thus providing an anxiety buffer from the knowledge that there is no immortality. Attraction to leisure, or 'leisure drive', was also favored by selection because it provided effective distraction for a period of time- -at least through young adulthood-sufficient to achieve at least some fertility before it had a chance to become compromised by the crippling anxiety from knowing that there is no immortality [39]. [According to 'terror management theory' [46], mortality salience also accounts for 'anxiety buffers' involving efforts aimed at validating one's cultural world view and bolstering selfesteem].

An intrinsic desire for memetic legacy transmission through offspring was favored by natural selection, therefore, because offspring are also the primary vehicles of genetic legacy. A critical consequence of these effects - in addition, ironically, to fitness rewards resulting from anxiety in knowing that we are not immortal-is that our evolved 'legacy drive' could also be satisfied through meme transmission associated with attraction to personal human accomplishments. Together with the evolution of attraction to leisure (including through materialism/consumerism), these dispositions can be interpreted as principal drivers of cultural evolution [45]. But importantly, just males - because of enforced patriarchal dominance throughout most of human evolution-historically have had widespread freedom to engage in both leisure and meme transmission through personal accomplishments, without compromising gene transmission, and so without any penalty on fitness.

This uncontested relationship between gene transmission and meme transmission, however, changed dramatically over the past century with the widespread erosion of patriarchy, and emancipation for women. Now empowered with control over their own fertility, many women today choose little or none, because they are also now empowered to engage in their intrinsic attraction (inherited from ancestors) to both leisure and legacy through accomplishment-based meme transmission - which for women necessarily conflicts with the time and energy required for offspring production (gene transmission). Importantly, any inclination for compromising fertility in favor of opportunity for leisure or meme transmission never had earlier opportunity to be significantly disfavored by selection in women, simply because their fertility was largely controlled by men; women who preferred to be 'childfree' could rarely exercise that choice throughout countless generations of patriarchal dominance over the course of human evolution [39]. For the same reason, there has been no significant historical opportunity for selection to favour strong 'parenting drive' in women, who were largely forced to bear offspring regardless of their levels of attraction to parenthood. Throughout most of human history, most men who became fathers did so only because they wanted sex or wanted to leave a legacy - and most women who became mothers did so also largely because men wanted sex or wanted to leave a legacy, regardless of whether women also wanted to produce offspring (as a legacy) or wanted to be mothers per se. Accordingly, men who had low fertility preferences always had the freedom to express those preferences, and so there was potential opportunity for selection to disfavour genes that might influence those preferences. By comparison, for women historically, the same freedom and potential were essentially negligible.

From the above effects, we might expect that contemporary fertility preferences should be generally higher for males than for females, but this was not detected in the present study - possibly because male fitness in our predecessors was so much more significantly correlated with sex drive than with legacy drive through offspring, or with parenting drive. Contemporary fertility preference in males might also be modulated by the relatively recent cultural norm espousing gender neutrality, where young men (unlike their male ancestors) generally learn that they will be expected to invest in child-rearing effort equally with their mates [47]. In addition, attraction to memetic legacy (for both males and females) "... may be may be associated with a modern perception (in wealthy countries) that success in meme transmission will be generally greater when a parent invests in fewer, and hence better-endowed (as opposed to many, poorly-endowed) offspring. This may stem from a perception that, by having fewer better-endowed offspring, there is a greater likelihood of promoting personal legacy for the parent through greater accumulation of descendants who-although not particularly numerous-will have wealth, fame, status, etc., and thus greater potential to impact on the thoughts and actions of others in future generations. This personal legacy for the parent is particularly facilitated when descendants bear the parent's family name - a widespread cultural tradition associated almost exclusively with male parenthood" [38, p. 295].

The average estimated lifetime fertility for women in Canada is currently about 1.6 [48]. How then can we explain the higher average lifetime fertility preference of 2.24 offspring for women in our study? It seems reasonable to speculate that socio-cultural learning by female university students might instill a general expectation that they 'should' want and 'should' have about two offspring as the 'ideal' family size [49] — but that as young adulthood progresses for liberated women, this conditioning is thwarted for many by the effects of strong legacy drive and leisure drive inherited from ancestors. Only $10 \%$ of our female respondents (mostly university students) indicated a lifetime fertility preference of zero offspring, but recent data indicate that by the time North American women reach between 40 and 44 years of age, $18 \%$ of this age group have remained childless [35]. It is also intriguing, we suggest, to speculate that the higher mean lifetime fertility preference for the predominantly young women in our survey might represent a signal of an emerging culture driven to a large extent by an intrinsic attraction to parenthood-'parenting drive'.

\section{Concluding Remarks}


Although survey results such as these are not representative of all segments of all societies, our results provide compelling evidence that gene-meme transmission competition is more evident in the behavior of women compared with men - at least in our sample population. This has an interesting parallel - from the sociological literature - in the "motherhood penalty": a per-child wage loss [50, 51]. These results of course involve only correlation but it is reasonable to expect that 'cause' and 'effect' work both ways. Women (and not men) therefore, it seems, generally perceive that personal achievements must necessarily compromise parenthood, and/or that parenthood must necessarily compromise personal achievements. In other words, our results suggest that some females have relatively strong memetic legacy drive which compromises their attraction to fertility (parenthood), whereas other females have relatively high fertility preference which compromises their attraction to accomplishment-based memetic legacy.

We propose that the childfree culture has become conspicuous only relatively recently because many women today have acquired not only widespread empowerment to control their own fertility (relatively recently), but they have also inherited genes from female ancestors who were not attracted to a life goal involving motherhood, but were nevertheless forced to endure it. Their descendants then-many women alive today-can now freely realize the lifestyle and life course goals that their maternal ancestors wished for, but were denied because of patriarchal subjugation. Accordingly, the widespread trend of below-replacement fertility in developed nations can be interpreted, to a significant extent, we suggest, as a product of behavioral preferences that are uniquely female. The childfree culture is now attracting urgent concern from both economists and politicians [52-54], including in Canada; a recent cover of Canada's national magazine (MacLean's, May 28, 2007) proclaim's: "Hey Lady! What will it take to make you breed? Your government needs to know." Some view this birth dearth as a reproductive revolution, leading inevitably (and soon) to a worldwide population crash [55]. Maybe so, but according to the transmission-competition hypothesis, the childfree culture is a byproduct of Darwinian natural selection - selection that is now acting strongly against it; 'childfree' unequivocally and immediately means zero gene transmission through direct lineage.

The above considerations present some intriguing questions and predictions. Assuming that the current patrons of the childfree culture indeed remain largely childless, and assuming that this behavioural preference is modulated at least to some extent by influencing effects of genes (associated with strong leisure drive and legacy drive, with modernday inclinations for its pursuit through personal accomplishments), we can predict that few children of the futureeven within the next generation alone-are likely to inherit a 'childfree' disposition. And neither will they inherit a leisure drive or legacy drive that is prone to compromise fertility. With women continuing rapidly, on a global scale, to acquire greater control over their own fertility, is it possible that natural selection is only now able to strongly favor a conspicuous 'parenting drive' in women, for the first significant time in human evolution $[39,56]$ ? Will this include continuing motivation to advance and adopt 'fertility' technologies such as egg freezing, sperm banks, in vitro fertilization-or even eventually, human cloning and 'transhumanism' [57]? We contend that this is a very real possibility, and the demographic implications are troubling for a world already overcrowded. Natural selection, by definition, favors any trait that propels genes into future generations, and a 'parenting drive' is nothing if it is not that. In a world with finite resources, an individual can leave on average only one descendant, yet "it is an intriguing paradox ... that natural selection continually favors individuals that leave more" [58, p. 650]. Individuals that intentionally limit their reproductive success will always, eventually, be excluded from genetic legacy by those who don't.

\section{CONFLICT OF INTEREST}

None declared.

\section{ACKNOWLEDGEMENTS}

Financial support was provided by a research grant to LWA from the Natural Sciences and Engineering Research Council of Canada.

\section{REFERENCES}

[1] World Databank. Indicators: fertility rate, (total) births per woman. http://data.worldbank.org/indicator/SP.DYN.TFRT.IN, Washington, DC: The World Bank 2010

[2] Westoff C F. Desired Number of Children: 2000-2008. DHS Comparative Reports No. 25. Produced for the United States Agency for International Development, Calverton, Maryland, USA: ICF Macro 2010.

[3] Gerson K. Hard Choices: How Women Decide about Work, Career and Motherhood. Berkeley: University of California Press 1986.

[4] Van de Kaa DJ. Postmodern fertility preferences: from changing value orientation to new behavior. Pop Dev Rev 2001; 27(Supplement): 290-331.

[5] Whitehead BD, Popenoe D. Life without children: the social retreat from children and how it is changing America. Piscataway, NJ: Rutgers, The State University of New Jersey, Avialable at: http://marriage.rutgers.edu; 2008.

[6] Preston SH, Hartnett C S. The future of American fertility. Cambridge, MA: National Bureau of Economic Research 2008.

[7] Barkow J H, Burley N. Human fertility, evolutionary biology, and the demographic transition. Ethol Sociobiol 1980; 1: 163-80.

[8] Borgerhoff Mulder M. The demographic transition: Are we any closer to an evolutionary explanation? TREE 1998; 13: 266-270.

[9] Kohler H P. Comments on Morgan and King (2001): Three reasons why demographers should pay attention to evolutionary theories and behavior genetics in the analysis of contemporary fertility. Eur J Pop 2001; 17: 31-5.

[10] Lawson DW, Mace R. Optimizing modern family size: trade-offs between fertility and the economic costs of reproduction. Hum Nat 2010; 21: 39-61.

[11] Agrillo C, Nelini C. Childfree by choice: a review. J Cult Geogr 2008; 25: 347-63.

[12] Reti I. Childless by choice: a feminist anthology. Santa Cruz, CA: Herbooks 1992.

[13] Bartlett J. Will you be mother? Women who choose to say no. New York: NYU Press 1995.

[14] Safer J. Beyond motherhood: choosing a life without children. New York: Pocket Books 1996.

[15] Lisle L. Without child: challenging the stigma of childlessness. Milton Park, UK: Routledge 1999.

[16] Lunneborg P. The chosen lives of childfree men. Santa Barbara, CA: Praeger 1999.

[17] Carroll L. Families of two: interviews with happily married couples without children by choice. Bloomington, IN: Xlibris Corporation 2000. 
[18] Maushart S. The mask of motherhood: how becoming a mother changes our lives and why we never talk about it. London: Penguin Books 2000

[19] Cain M. The childless revolution. New York: Perseus 2001.

[20] Jeffers S. I'm okay, you're a brat. Los Angeles, Renaissance Books 2001.

[21] Metter E. Cheerfully childless. Denver: Browser Press 2001.

[22] Buchanan AJ. Mother shock. Berkeley, CA: Seal Press 2003.

[23] Douglas S, Michaels M. The mommy myth. New York: Free Press 2004.

[24] Defago N. Childfree and loving it. Harrisonburg, VA: Vision 2005.

[25] Shawne JL. Baby not on board. San Francisco: Chronicle Books 2005.

[26] Moore S, Moore D. Childfree zone: why more people are choosing not to be parents. Dee Why, NSW, Australia: Chequered Gecko 2005.

[27] Van Luven L. Nobody's mother: life without kids. Victoria, Canada: Touchwood Editions 2006.

[28] Eckler R. Wiped: life with a pint-sized dictator. New York: Random House 2007.

[29] Leibovich L. (Ed.). Maybe baby. New York: HarperCollins 2007.

[30] Sindoni J. 50 reasons not to have kids. New York: Infinity Publishing 2007.

[31] Casey T. Pride and joy: the lives and passions of women without children. Hillsboro, OR: Beyond Words Publishing; 2007.

[32] Glembocki V. The second nine months: one woman tells the real truth about becoming a mom - finally. Cambridge, MA: Da Capro Press 2008.

[33] Scott LS. Two is enough: a couple's guide to living childless by choice. Berkeley, CA: Seal Press 2009.

[34] Maier C. No kids: 40 good reasons not to have children. Toronto: McClelland \& Stewart 2009.

[35] Livingston G, Cohn D. Childlessness up among all women; down among women with advanced degrees. Pew Research Center's Social \& Demographic Trends Project 202.419.4372 http://pewsocialtrends. org; 2010.

[36] Miranti R., McNamara J, Tanton R., Yap M. A narrowing gap? Trends in the childlessness of professional women in Australia 1986-2006. J Pop Res 2009; 26: 359-79.

[37] Boddington B, Didham R. Increases in childlessness in New Zealand. J Pop Res 2009; 26: 131-51.

[38] Aarssen LW, Altman ST. Explaining below-replacement fertility and increasing childlessness in wealthy countries: Legacy drive and the 'transmission competition' hypothesis. Evol Psychol 2006; 4: 290-302.

[39] Aarssen LW. Some bold evolutionary predictions for the future of mating in humans. Oikos 2007; 116: 1768-78.
[40] Van Heek F. Roman-Catholicism and fertility in the Netherlands: demographic aspects of minority status. Pop Studies 1956; 10: 12538.

[41] Francis LJ. The psychology of gender differences in religion: A review of empirical research. Religion 1998; 27: 81-96.

[42] Kosmin BA, Keysar A. American religious identification survey (ARIS 2008). http://www.americanreligionsurvey-aris.org/, Hartford, Connecticut: Trinity College 2009.

[43] Mace R. The evolutionary ecology of human family size. In: Dunbar RIM, \& Barrett L. Eds. The Oxford handbook of evolutionary psychology Oxford: Oxford University Press 2007; pp. 383-96.

[44] Stamos DN. Evolution and the big questions: sex, race religion and other matters. Oxford, UK: Blackwell 2008.

[45] Aarssen LW. Darwinism and meaning. Biol Theory 2010; 5: 296311.

[46] Greenberg J, Solomon S, Pyszczynski T. Terror management theory of self-esteem and cultural worldviews: empirical assessments and conceptual refinements. Adv Exp Soc Psych 1997; 29: 61-139.

[47] Bronstein P, Cowan CP. (Eds). Fatherhood today: Men's changing role in the family. New York: Wiley 1988.

[48] Statistics Canada. Births. on June 16, 2009 from: http://www.statcan.gc.ca/daily-quotidien/080926/dq080926aeng.htm; 2008

[49] Livingston G, Cohn D. The new demography of American motherhood. Pew Research Center's Social \& Demographic Trends Project 202.419.4372 http://pewsocialtrends.org; 2010.

[50] Correll SJ, Benard S, Paik I. Getting a Job: is there a motherhood penalty? Am J Soc 2007; 112: 1297-338.

[51] Wolfinger NH, Mason MA, Goulden M. Stay in the game: gender, family formation and alternative trajectories in the academic life course. Social Forces 2009; 87: 1591-621.

[52] Douglass CB. (Ed.). Barren States: The Population Implosion in Europe. Oxford: Berg Publishers 2005.

[53] McDonald P. Low fertility and the state: the efficacy of policy. Pop Dev Rev 2006; 32: 485-510.

[54] Klingholz R. Population: Europe's big experiment. New Sci 2009; 203 (2727): 41

[55] Pearce F. The coming population crash and our planet's surprising future. Boston, MA: Beacon Press 2010.

[56] Rotkirch A. 'All that she wants is a(nother) baby?' Longing for children as a fertility incentive of growing importance. J Evol Psych 2007; 5: 89-104.

[57] Bostrum N. A history of transhumanism thought. J Evol Tech 2005; 14: 1-25.

[58] Harper JL. 1977. Population biology of plants. London: Academic Press 1977.

(C) Aarssen and Altman; Licensee Bentham Open.

This is an open access article licensed under the terms of the Creative Commons Attribution Non-Commercial License (http://creativecommons.org/licenses/by-nc/3.0/) which permits unrestricted, non-commercial use, distribution and reproduction in any medium, provided the work is properly cited. 